\title{
KANDUNGAN TOTAL FENOL DALAM RUMPUT LAUT Caulerpa racemosa YANG BERPOTENSI SEBAGAI ANTIOKSIDAN
}

\author{
Fera Yusniarti Djapiala. Lita. A.D.Y. Montolalu. Feny Mentang \\ 1) Mahasiswa Fakultas Perikanan dan IImu Kelautan Unsrat \\ 2) Staf Pengajar Fakultas Perikanan dan IImu Kelautan Unsrat
}

\begin{abstract}
ABSTRAK
Tujuan penelitian ini adalah untuk meenentukan total fenol dari ekstrak methanol Caulerpa racemosa kering dan mempelajari aktivitas antioksidan yang diekstrak dengan methanol dari rumput laut Caulerpa racemosa kering. Pada ekstrak methanol rumput laut Caulerpa racemosa setelah diidentifikasi dengan beberapa uji yang diterapkan seperti (uji total fenol,uji aktivitas antioksidan DPPH, uji FRAP dan uji pengkelat ion membuktikan bahwa adanya aktivitas antioksidan yang berada didalam ekstrak. Dapat dilihat dari hasil pengujian pada setiap uji yang dilakukan berturut turut : pada uji total fenol di dapatkan hasil 1335.59, 2165.62, $2624.62 \mathrm{mg}$ GAE/gr, uji aktifitas antioksidan metode DPPH didapatkan nilai $(31.33,31.00,30.88) \%$ Penghambata, uji FRAP didapatkan nilai berturut - turut 46.76, 46.31, 46.62 mg/ml dan uji pengkelt ion didapatkan nilai ( 63.79, 64.22, 65.52)\%. Pada pengujian kandungan total fenol tidak berkorelasi positif dengan aktifitas antioksidan yang terdapat dalam ekstrak rumput laut Caulerpa racemosa. hal ini dikarenakan tidak semua senyawa fenol yang diekstrak dalam pelarut methanol merupakan senyawa fenol yang dapat berfungsi sebagai antioksidan yang dapat dilihat pada pengujian aktivitas antioksidan berbanding lurus dengan pengkelat ion.
\end{abstract}

\section{Kata Kunci : rumput laut, antioksidan}

\section{PENDAHULUAN}

Makanan yang kita konsumsi di masa sekarang sudah banyak mengandung bahan - bahan tambahan yang apabila di konsumsi dengan kadar yang berlebihan akan berdampak buruk bagi tubuh. Akibatnya berbagai penyakit bermunculan menyerang tubuh kita. Hal itu semua tak luput dari adanya radikal bebas.Radikal bebas adalah atom atau gugus yang memiliki satu atau lebih elektron tidak berpasangan. Radikal bebas juga dijumpai pada lingkungan, beberapa logam (contohnya besi dan tembaga), asap rokok, obat, makanan dalam kemasan, bahan aditif, dan lain-lain (Droge, 2002: Stevi G. dkk. 2012).

Radikal bebas ini dapat dihindari dengan antioksidan yang dihasilkan oleh tubuh. Akan tetapi kadarnya sedikit,melihat dari penyakit - penyakit yang diderita oleh manusia sekarang ini, antioksidan yang diproduksi oleh tubuh sudah tidak cukup melawan radikal - radikal bebas penyebab penykit. Hal ini mendorong setiap manusia harus membutuhkan tambahan asupan antioksidnan dari luar tubuh.Karena salah satu fungsi antioksidan ini dapat menghentikan reaksi dari radikal bebas. Menurut Kaur dan Kapoor (2001) dalam Maulida (2007), berdasarkan cara reaksinya antioksidan didefinisikan sebagai komponen yang dapat menghentikan rantai radikal bebas pada oksidasi lemak dengan cara memberikan electron atau atom hydrogen pada lemak yang mengandung radikal bebas.

Maulida R. (2007) Menyatakan sumber antioksidan bisa kita dapatkan dari makanan yang kita konsumsi, baik secara alami maupun sintetis. Antioksidan yang diperoleh dari asupan makanan yang kita konsumsi dapat digolongkan menjadi 2 bagian yaitu antioksidan zat gizi dan antioksidan nongizi selain itu adapun antioksidan yang sering digunakan pada bahan pangan seperti butylated hydroxytoluene (BHT), Butylated Hydroxyanisole
(BHA), propyl Gallate (PG) dan Nordihidroquairetic Acid (NDGA).

Penggunaan antioksidan sintesis pada setiap bahan pangan harus terkontrol secara baik, karena apabila pemakaiannya terlalu berlebihan fungsi antioksidan tersebut akan berubah menjadi racun di dalam tubuh kita. Sehingga antioksidan alami lebih baik digunakan untuk menambah asupan antioksidan yang tubuh kita butuhkan.salah satu bahan pangan yang menjadi sumber antioksidan alami adalah Alga laut (Tri Dewanti. 2006). Peneliti lain juga melaporkan seperti Chew et al (2007), Suresh Kumar et al (2008) dan Tao Wang.et al (2009) bahwa rumput laut mengandung fenol yang mempunyai aktivitas sebagai antioksidan yang ditunjukan oleh kandungan fenol dan aktivitas antioksidan pada rumput laut tersebut melalui berbagai metode uji.

Rumput laut adalah tanaman laut yang mengandung senyawa fenol yang berfungsi sebagai antioksidan, juga kaya akan serat lodium dan mineral-mineral penting lainnya. Selain itu rumput laut mengandung senyawa-senyawa fitokimia lainnya yang penting untuk kesehatan dan mempertahankan mutu pangan.Antioksidan pada rumput laut dapat melawan radikal bebas dalam tubuh.dimana radikal bebas adalah suatu molekul yang pada orbit terluarnya mempunyai satu atau lebih elektron yang tidak berpasangan, sifatnya sangat labil dan sangat reaktif sehinggah dapat menimbulkan kerusakan pada tubuh manusia (Chen et al, 1996 :Fithrani. D, 2009). Antioksidan sangat bermanfaat bagi kesehatan yaitu dapat mencegah antara lain pemicu penyakit regeneratif seperti : kanker, jantung, katarak , diabetes, hati, penuaan dini dan antioksidan juga dapat mempertahankan mutu produk pangan (Silalahi, 2002 : Fithriani. D, 2009).

Di perairan Sulawesi utara ini selain memiliki potensi di bidang perikanan yaitu jenis dan jumlah ikan yang ditangkap, juga mempunyai potensi sebagai ladang rumput laut.Dimana salah satu 
produksi rumput laut tersebut telah menjadi salah satu mata pencaharian masyarakat Sulawesi utara. Hal ini dapat dilihat pada data produksi rumput laut Dinas Kelautan dan Perikanan (2013) .

Akan tetapi produksi rumput laut tersebut hanya pada jenis rumput laut tertentu seperti Kappapiccus alfarezyyang telah dibudiyakan.Padahal masih banyak rumput laut yang tumbuh liar disekitar perairan laut Sulawesi utara dan mempunyai manfaat yang baik apabila dikonsumsi.Hal ini telah banyak penelitian yang menyatakan bahwa rumput laut merupakan sumber yang kaya akan senyawa antioksidan (Ganesan et al. 2008 : Fithrani. D, 2009).Salah satu jenis dari rumput laut tersebut yaitu Caulerpa racemosa. Jenis rumput ini telah banyak tumbuh pada perairan Sulawesi utara, akan tetapi pemanfaatannya belum maksimal dikarenakan hanya masyarakat pesisir pantai saja yang banyak mengkonsumsi rumput laut tersebut sebagai sayuran.

Caulerpa racemosa memiliki kemampuan menghasilkan sumber antioksidan (Fithrani. D, 2009). Sifat Caulerpa racemosa yang aman dikonsumsi dan telah dimanfaatkan sebagian masyarakat pesisir sebagai sayuran segar, memungkinkan rumput laut ini dapat dieksplorasi sebagai sumber antioksidan alami.

Kondisi rumput laut (segar atau kering) dapat mempengaruhi senyawa aktif karena kebanyakan komponen aktif tidak tahan terhadap suhu tinggi selama pengeringan. Santoso dkk (2010), melaporakan bahwa kandungan total fenol dan kemampuan menangkap radikal bebas DPPH ekstrak metanol dan etil asetat Caulerpa lentillifera segar lebih tinggi dari $C$. Lentillifera yang dikeringkan. Perlakuan kondisi rumput laut ini juga penting karena Caulerpa sp kebanyakan dikonsumsi oleh masyarakat dalam bentuk segar sebagai salad, karena bila rumput laut segar mempunyai aktivitas antioksidan lebih tinggi, maka hal ini menjadi mitovasi bagi masyarakat untuk meningkatkan konsumsi rumput laut segar tersebut.

Sejauh ini informasi tentang antioksidan dalam rumput laut yang tumbuh diperairan laut Sulawesi Utara belum ada. Tujuan penelitian ini adalah 1). Menentukan total fenol dari ekstrak methanol Caulerpa racemosa kering. 2). Mempelajari aktivitas antioksidan yang diekstrak dengan methanol dari rumput laut Caulerpa racemosa kering.

\section{METODOLOGI PENELITIAN}

\subsection{Alat dan Bahan}

Bahan baku penelitian terdiri atas: alga laut Caulerpa racemosadiambil di perairan Teluk Manado, Sulawesi Utara. Bahan kimia yang digunakan untuk analisa ialah: metanol, diperoleh dari laboratorium kimia FMIPA. Bahan untuk analisa kandungan total fenol yaitu etanol $96 \%$, larutan Folin Ciocalteau, natrium karbonat, asam galat/asam tanat; bahan untuk uji DPPH yaitu: 1,1-Difenil-2pikrihidrazil; bahan untuk uji daya reduksi yaitu: buffer fosfat; potasium ferrisianida $\left[\mathrm{K}_{2} \mathrm{Fe}(\mathrm{CN})_{6}\right]$, asam trikloroasasetat, air estilat, $\mathrm{FeCl}_{3}$ diperoleh dari laboratorium ADVANS

Peralatan yang digunakan yaitu cold box, pisau stainless steel,kantong plastik. Peralatan untuk analisis yaitu:GC, GC-MS dan FT-IR(vaccum rotary evaporator), freezer, freez dryer, sentrifus magnetik stirrer, timbangan analitik, alat-alat gelas.

\subsection{Preparasi Dan Analisa Sampel}

\subsubsection{Preparasi Sampel}

Adapun penyiapan sampel rumput laut segar adalah sebagai berikut :

- Sampel diambil dari perairan laut Arakan Minahasa Selatan, kemudian sampel dibawa ke laboratorium penanganan dan pengolahan Hasil Perikanan (PPHP).

- Sampel segar dicuci bersih dengan air tawar untuk menghilangkan kotoran yang menempel

- pada rumput laut juga menghilangkan sebagian garam.

- Sampel kemudian ditiriskan untuk mengeluarkan sisa air.

- Sampel segar ditimbang sebanyak $1 \mathrm{~kg}$.

- Sampel dikeringkan dengan cara dianginanginkan dalam ruangan selama 3 hari dan dilanjutkan dengan pengeringan dalam cabinet dryer selama 4 jam suhu $40^{\circ} \mathrm{C}-46$ ${ }^{\circ} \mathrm{C}$ sehingga berat sampel berkurang 10 kali dari berat sampel segar.

- Sampel kering diblender halus dan ditimbang 25 gram.

- Sampel kering sebanyak $25 \mathrm{~g}$ dimaserasi dalam wadah kaca (toples) dengan $500 \mathrm{ml}$ menggunakan pelarut methanol selama 48 jam, dan disaring melalui kertas saring whatman no 1 dengan penyaring vakum dan ditampung dalam botol kaca.Maserasi dan penyaringan diulangi 3 kali dengan cara yang sama sehingga diperoleh 1,5 liter maserat.

- Hasil maserasi sampel sebanyak 1,5 liter diuapkan dengan evaporator vakum suhu $40^{\circ} \mathrm{C}$ sehingga diperoleh ekstrak cair, kemudian dituang dalam botol kaca berwana gelap.

- Selanjutnya ekstrak cair yang ada di dalam botol dituang ke dalam cawan petri dan dikeringkan dalam oven suhu $40^{\circ} \mathrm{C}$ hingga diperoleh ekstrak semi padat, ekstrak ini disimpan dalam lemari pendingin suhu $4^{\circ} \mathrm{C}$ untuk dianalisa selanjutnya. Analisis ini dilakukan di laboratorium Kimia Bahan Hayati Laut (KBHL) Fak Perikanan UNSRAT.

- Selanjutnya dianalisis Total Kandungan Fenol dan aktifitas antioksidan (DPPH, FRAP, Pengkelat Ion). Analisis Ini dilaksanakan di laboratorium Advance MIPA Unsrat.

\subsection{Analisa Sampel}

\subsubsection{Analisa Kandungan Total Fenol}

Analisa total fenol diukur dengan spektrofotometer menggunakan pereaksi Folin- 
Ciocalteau. Ekstrak rumput laut kering kosentrasi 10000 ppm, diambil sebanyak 0,1 ml kemudian di tambahkan Folin ciocelteau dengan perbandingan (1:2) dimana ( $1 \mathrm{ml}$ reagen $+2 \mathrm{ml}$ Aquades) . kemudian diforteks lalu didiamkan selama 5 menit, selanjutnya ditambahkan $1 \mathrm{ml} \mathrm{Na2CO} 3 \%$ dan diinkubasi selama 30 menit. Lalu dibaca pada absorbansi dengan panjang gelombang $750 \mathrm{~nm}$.

Sebagai Standar digunakan asam galat. Pembuatan standar asam galat yaitu dengan cara membuat larutan induk 200 ppm. Penentuan kurva standar dilakukan sama dengan penentuan sampel. Perhitungan total fenol sampel berdasarkan hasil ploting nilai absorbansi pada kurva standar. Kurva standar menggunakan asam galad dengan konsentrasi $0,20,40,60,80,100,120,140,160$, 180 dan 200 ppm. Dari hasil pengujian diperoleh persamaan kurva standar adalah sebagai berikut: $Y$ $=0.0051 x-0.0159$ dengan $\mathrm{R} 2=0.09957$.

\subsubsection{Analisa Aktivitas Antioksidan Dengan Metode DPPH}

Uji aktivitas antioksidan dilakukan dengan metode DPPH berdasarkan kemapuan sampel untuk mereduksi radikal bebas stabil DPPH. 1. 1, 1-difenil2-pikrilhidrazil (DPPH) Uji radikal bebas DPPH dapat dilakukan dalam tiga tahapan, Aktivitas penangkalan radikal bebas dari ekstrak rumput laut Caulerpa racemosa dapat diukur dengan pengujian radikal DPPH yaitu dengan mereaksikan $0,5 \mathrm{~mL}$ ekstrak rumput laut Caulerpa racemosa dengan $2 \mathrm{~mL}$ larutan DPPH dan absorbansinya diukur pada $\lambda 517$ $\mathrm{nm}$ yang merupakan panjang gelombang maksimum. Ekstrak rumput laut Caulerpa racemosa memiliki kemampuan sebagai penangkal radikal bebas yang sangat baik, hal ini dibuktikan dengan perubahan warna ungu menjadi warna kuning, dan ketika ekstrak ditambahkan larutan DPPH.

DPPH dinyatakan dalam kapasitas antioksidan dengan rumus : inkubasi $\%=\left(\frac{A B-A S}{A B}\right) \times 100 \%$

Dimana, $A B=$ Absorbansi Blanko/Kontrol AS = Absorbansi Sampel

\subsubsection{Analisa Daya Pereduksi Antioksidan Metode FRAP (Ferrous Reduction Antioxidan Power)}

Pengujian dilakukan dmulai dari Ekstrak metanol rumput laut kering disiapkan, potensial reduksi dari ekstrak ditentukan sebagai berikut: ekstrak dengan konsentrasi 4000 ppm diambil $1 \mathrm{ml}$ dan ditambahkan dengan buffer fosfat $(2,5 \mathrm{ml}, 0,2$ $\mathrm{M}, \mathrm{pH} 6,6)$ dan potasium Ferricianida [K3Fe(CN)6] 1 $\%$. Campuran diinkubasi pada suhu $500 \mathrm{C}$ selama 20 menit . lalu ditambahkan $1 \mathrm{ml}$ dari asam trikloroasetat (10\%).Selanjutnya disentrifuse dalam $3000 \mathrm{Rpm}$, lapisan atas dari larutan sebanyak $1 \mathrm{ml}$ dicampur dengan aquades $1 \mathrm{ml}$ dan $\mathrm{FeCl} 3(0,5 \mathrm{ml}$, $0,1 \%$ kemudian diabsorbansi pada panjang gelombang $700 \mathrm{~nm}$. Absorbansi tertinggi dari campuran reaksi menunjukkan potensial reduksi tertinggi.

\subsubsection{Analisa Kemampuan Pengkelat Ion Metode FIC ( Ferrous lon Chelating) \\ Uji FIC didasarkan dari ekstrak 0,5 ml} ditambahkan 1,85 $\mathrm{ml}$ aquades steril, dicampur dengan 0,5 $\mathrm{ml} \mathrm{FeSO} 4$ 0,1 mm kemudian di aduk dan ditambahkan $0,5 \mathrm{ml}$ ferrozine $0.25 \mathrm{~mm}$. Dengan menggunakan volume yang sama campuran reaksi tersebut dilakukan tiga ulangan kemudian diinkubasi selama 10 menit dan absorbansi diukur pada 562 $\mathrm{nm}$. Hasilnya dinyatakan dalam persentase kemampuan pengkelat (\% kemampuan mengkelat). menggunakan persamaan :

Kemampuan pengkelat $(\%)=\left[\left(A_{\text {kontrol }}-A_{\text {sampel }}\right) / A_{\text {kontrol }}\right] \times 100$ Dimana :

$A_{\text {kontrol }}=$ Ability control ( kemampuan control)

$A_{\text {sampel }}=$ Ability control ( kemampuan sampel)

\section{HASIL DAN PEMBAHASAN}

Berdasarkan hasil pengukuran, kadar total fenol berturut-turut adalah 1335.59, 2165.62, $2624.62 \mathrm{mg}$ GAE/gr. Pengujian aktivitas total fenol merupakan dasar dilakukan pengujian aktivitas antioksidan, karena diketahui bahwa senyawa fenolik berperan dalam mencegah terjadinya peristiwa oksidasi. Pengukuran total antioksidan bahan pangan asal tanaman dapat dilakukan dengan mengukur kadar total fenolik menggunakan reagen Folin-ciocalteau. Hal ini karena sebagian besar antioksidan dalam bahan asal tanaman merupakan senyawa polifenol. Menurut Shahidi dan Marian (1995) dalam Yulia O. (2007) pengujian total fenol bertujuan untuk menentukan total senyawa fenolik yang terkandung di dalam sampel, sehingga diduga bila kandungan senyawa fenolik di dalam sampel tinggi maka aktivitas antioksidannya akan tinggi. Analisis ini menggunakan kurva standar yang dipersiapkan dengan menggunakan asam galat.

Dari hasil ekstrak methanol Caulerpa rasemosa pada kosentrasi 10.000 ppm pengukuran yang didapat menunjukkan adanya kenaikan yang signifikan. Diduga dengan adanya kenaikan total fenol maka adanya pula aktivitas antioksidan yang berlangsung. Karena kandungan total fenol dapat dihasilkan dari sejumlah molekul sederhana yaitu senyawa fenolik, sampai dengan molekul yang kompleks tannin yang bisa larut dalam pelarut methanol ( Stevi G. dkk. 2012). Hai ini menunjukkan adanya senyawa - senyawa fenolik pada ekstrak caulerpa racemosa, akan tetapi kandungan total fenol tidak berkorelasi positif dengan aktifitas antioksidan yang terdapat dalam ekstrak rumput laut Caulerpa racemosa. Karena tidak semua senyawa fenol yang diekstrak dalam pelarut methanol merupakan senyawa fenol yang dapat berfungsi sebagai antioksidan. Contohnya saja lignin yang berfungsi sebagai bahan pembentuk dinding sel tanaman juga termasul kedalam golonga fenol namun fungsinya sebagai antioksidan belum diketahui (Maulida. R. 2007).

Lim et.al.(2002) dalam Maulida. R (2007) meneliti hubungan kandungan fenol dan aktivitas antioksidan pada rumput laut Sargasum siliquastrum. Dari penelitian itu dapat diketahui bahwa kandungan total fenol tidak menunjukkan hubungan yang positif 
dengan antioksidan. Hal itu mungkin disebabkan adanya lignin yang ikut terekstrak dapat mempengaruhi nilai kandungan total fenol serta aktivitas antioksidan dari rumput laut Sargassum siliquastrum.

Hasil penelitian serupa dilaporkan oleh Chew et. al. (2007) bahwa dalam 3 jenis ekstrak rumput laut yaitu $P$. antillarum, $C$. racemosa, $K$. alvarezzi, berturut - turut mempunyai nilai aktivitas yang cukup tinggi ( $1240,96.5,28.4) \mathrm{mg}$ GAE/gr, hal ini bila dibandingkan dengan hasil penelitian yang di dapat pada ekstrak methanol Caulerpa racemosa ini hamper serupa diduga pada jenis rumput laut ini memiliki aktivitas antioksidan yang tinggi dan mengandung gallokatekin, epikatekin dan katekin yang merupakan senyawa - senyawa turunan fenol. Komponen aktif ini mungkin memiliki efek sinergis yang berperan sebagai antioksidan. Senyawa fenol yang terdapat dalam ekstrak rumput laut Caulerpa racemosa tidak dilakukan identifikasi sehingga tidak dapat diketahui senyawa fenol apa saja yang terdapat pada ekstrak tersebut.

Berdasarkan hasil pengukuran menunjukkan 30.88 - 31. $33 \%$ penghambatan aktivitas antioksidan yang diukur pada kosentrasi 4000 ppm ( gambar 1).

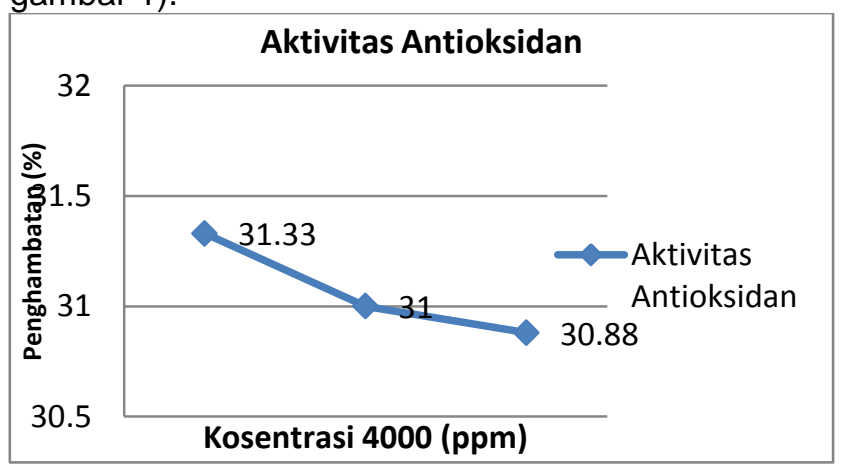

Gambar 1. Aktivitas Antioksidan Caulerpa racemosa

Hal ini menunjukkan bahwa telah terjadi penghambatan oleh senyawa yang terdapat dalam ekstrak rumput laut Caulerpa racemosa untuk meredam DPPH (1,1, difenil 2- pikrihidrazil) dimana hal tersebut menunjukkan adanya aktivitas antioksidan yang berlangsung didalamnya. Sebaliknya, dibandingkan dengan hasil control dalam hal ini antioksidan sintetik (BHT) pada ekstrak caulerpa resemosa ini hasil aktivitasnya masih jauh lebih tinggi, hal ini diduga karena dalam ekstrak Caulerpa rasemosa ini masih ada senyawa senyawa tertentu yang belum terpisah dan juga adanya senyawa lain yang bias sebagai penghambat aktivitas senyawa yang berperan sebagai antioksidan dalam ekstrak Caulerpa racemosa ini dihubungkan dengan jumlah total fenol, aktivitas antioksidan ini tidak menunjukkan adanya hubungan yang positif karena diduga ada senyawa - senyawa tertentu pula yang bila bereaksi dengan senyawa DPPH bukan berfungsi untuk meredam senyawa tersebut tapi mempunyai fungsi lain sehingga mempunya efek dalam aktivitas antioksidan yang berlangsung.

Dwi S. dkk (2006) meneliti uji aktivitas senyawa antioksidan dari rumput laut Halymenia harveyana dan Eucheuma cottoni didapat nilai antioksidan pada fraksi methanol yaitu Halymenia harveyana ( $48.70 \%$ ) sampel kering dan pada ekstrak rumput laut Eucheuma cottoni ( $64.80 \%$ ) nilai tersebut lebih tinggi dibandingkan nilai antioksidan yang terdapat pada Caulerpa racemosa, hal ini diduga karena adanya pengaruh pada perlakuan yang dilakukan dalam preparasi sampel, dikarenakan antioksidan ini memiliki sifat yang mudah rusak terkena cahaya bila ditempatkan pada suhu tinggi dan pengeringan. Disamping itu Penggunaan pelarut yang tidak tepat dapat merusak aktivitas antioksidan yang ada. Karna setiap penggunaan pelarut yang sama dapat memberi hasil yang sangat berbeda, walaupun partikel dan stabilitas substrat sampel yang diekstraksi hampir sama ( Dwi S. dkk. 2006).

Dari pengujian daya pereduksi metode FRAP pada ekstrak rumput laut Caulerpa racemosa ini telah di dapatkan nilai tertinggi 46.31 ppm, yang dapat dilihat pada gambar 2 .

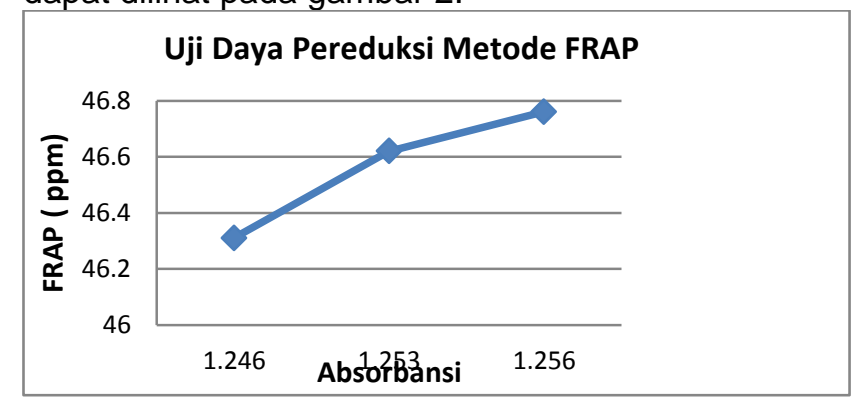

Gambar 2. Hasil Uji Daya Pereduksi Metode FRAP

Data diatas berbanding lurus, dimana pada ekstrak rumput laut Caulerpa racemosa ini menunjukan bahwa semakin besar nilai absorbansinya maka semakin tinggi pula daya pereduksi oleh senyawa antioksidan.Karena kandungan antioksidan yang terdapat didalamnya mampu mendonorkan electron untuk menutupi radikal bebas. Hal ini diperkuat oleh Ganessan. P.et.al. (2007) pada penelitian "Antioxidant properties of methanol extract and its solvent fractions obtained from selected Indian red seaweeds" dimanaekstrak rumput laut yang digunakan $P$. antillarum, $C$. racemosa dan $K$. alvarezzi mampu untuk mereduksi ion $\mathrm{Fe}^{3+}$ menjadi $\mathrm{Fe}^{2+}$.

Dalam pengujian pengkelet ion metode FIC pada ekstrak rumput laut Caulerpa racemosa ini didapat nilai tertinggi pada absorbansi 0,080 yaitu $65.52 \%$. Hal ini dapat dilihat pada gambar 3 .

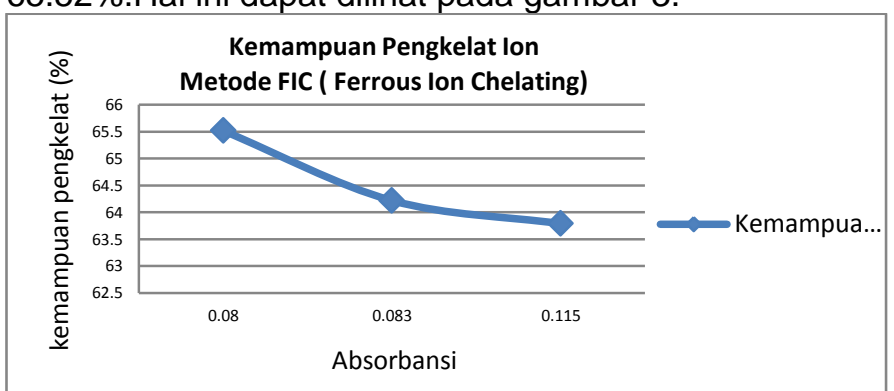

Gambar 3. Hasil kemampua pengkelat ion pada ekstrak methanol rumput laut Caulerpa racemosa 
Dilihat dari nilai tersebut absorbansi terkecil memiliki nilai pengkelat ion yang lebih tinggi, sama halnya dengan aktivitas antioksidan DPPH. sehingga hal ini dapat membuktikan nilai pengkelat ion berbanding lurus dengan aktivitas antioksidan pada ekstrak. Dimana semakin tinggi nilai aktivitas antioksidan pada ekstrak maka semakin tinggi pula nilai pengkelat ion yang didapat. Hal ini diperkuat oleh penelitian yang dilakuakan oleh Ganessan. $d k k$. 2007, dimana nilai kemampuan pengkelat pada 3 jenis rumput laut mempunyai nilai pengkelat ion yang cukup tinggi.karena pada jenis tumbuhan rumput laut memiliki banyak kandungan logam berat yang memiliki kemampuan sebagai pengkelat ion (Toth. dkk. 2000 : Baskar N. 2007 ).

\section{KESIMPULAN DAN SARAN}

\subsection{Kesimpulan}

Pada pengujian kandungan total fenol tidak berkorelasi positif dengan aktifitas antioksidan yang terdapat dalam ekstrak rumput laut Caulerpa racemosa. Hal ini dikarenakan tidak semua senyawa fenol yang diekstrak dalam pelarut methanol merupakan senyawa fenol yang dapat berfungsi sebagai antioksidan. Selain itu uji dilihat pada pengujian aktivitas antioksidan berbanding lurus dengan pengujian pengkelat ion, hal dilihat dari nilai pengujian pengkelat ion dimana semakin tinggi nilai yang didapat berarti semakin tinggi pula kemampuan mengkelat suatu ion dalam meredam radikal bebas sehingganya nilai aktivitas antioksidan yang didapat semakin tinggi pula.

\subsection{Saran}

Perlu diadakan penelitian lanjut tentang penerapan antioksidan Caulerpa racemosa pada bahan pangan perikanan.

\section{DAFTAR PUSTAKA}

Chew, Y. L.,Luin, Y.Y., Omar, M., K.S. Khoo. 2007. Antioxsidan Activity of Edible Seaweeds from Two Areas in South East Asia. LWT 41, 10671072.

Dwi Suryaninggrum., Thamrin Wikanta., Hendy Kristiana. 2006. Uji Aktivitas Senyawa Antioksidan Dari Rumput Laut Halymenia harveyana Dan Eucheuma ottonii. Jurnal Pascapanen dan Bioteknologi Kelautan dan Perikanan Vol. 1 No.1.

Fithriani D. 2009. Potensi Antioksidan Caulerpa racemosa Diperairan Teluk Harun Lampung. Thesis. Program Pasca sarjana. Institut Pertanian Bogor.

Ganesan P.,Chandini S. Kumar., N Bhaskar. 2007. Antioxidant Properties Of Methanol Extract And Its Solvent Fractions Obtained From Selected Indian Red Seaweads. Bioresource Technology 99, $2717-2723$.
Maulida R. 2007. Aktivitas Antioksidan Rumpul Laut Caulerpa lentillifera. SKRIPSI. Universitas Institut Pertanian Bogor.

Santoso. J., Maulida.R, dan Suseno. S.H. 2010. Aktivitas antioksidan ekstrak methanol, etil asetat dan heksana rumput laut hijau Caulerpa Lentillifera). IImu Kelautan Vol. Edisi Khusus: 1-10.

Suresh Kumar.k., Canusan.K., Subba Rai. P.V (2008). Antioxidant potential of solvent extract of Kappaphycus alvarezii (doty) doty-an edible seaweed. Food Chemistry 107, 289-295.

Stevi G. Dungira., Dewa G. Katja., Vanda S. Kamu. 2012. Aktivitas Antioksidan Ekstrak Fenolik Dari Buah Manggis ( Garcinia mongostana L). Jurnal MIPA ONLINE 1 (1) 11 - 15 . UNSRAT Manado.

Tao Wong., Rosa Jonsdottir., Gundrum Olafsdottia. (2009). Total phenolic compounds, radical scavenging and metal chelation of extract from Icelandic seaweed. Food Chemistry 116, 24248.

Tri Dewanti. W. (2006). Pagan Fungsional Makanan Untuk Kesehatan. Jurusan Teknologi Hasil Pertanian. Universitas Bwawijaya. Malang.

Winarsi H. 2007. Antioksidan Alami dan Radikal Bebas. Kanisius Media. Yogyakarta.

Yulia O. 2007. Pengujian Kapasitas Antioksidan Ekstrak Polar, Nonpolar, Fraksi Protein Dan Nonprotein Kacang Komak (Lablab purpureus (L.) sweet). Depertemen IImu Dan Teknologi Pangan. Institut Pertanian. Bogor. 